\title{
Pharmacovigilance: Effects of herbal components on human drugs interactions involving Cytochrome P450
}

\author{
Akansha Saxena, Kumar Parijat Tripathi, Sudeep Roy, Feroz Khan, Ashok Sharma \\ Bioinformatics and In Silico Biology Division, Central Institute of Medicinal and Aromatic Plants (Council of Scientific and Industrial Research), \\ Lucknow 226015 (UP), India; Feroz Khan* - Email: f.khan@cimap.res.in; Phone: 91522 2357133; Fax: 91522 2342666; * Corresponding \\ author
}

received November 9, 2008; accepted December 1, 2008; published December 31, 2008

\begin{abstract}
:
Cytochrome P450 (CYP P450) enzymes are a superfamily of mono-oxygenases that are found in all kingdoms of life. The CYP P450 enzymes constitute a large superfamily of haem-thiolate proteins involved in the metabolism of a wide variety of both exogenous and endogenous compounds. The CYP activities have been shown to be involved in numerous interactions especially between drugs and herbal constituents. The majority of serious cases of drug interactions are as a result of the interference of the metabolic clearance of one drug by yet another co-administered drug, food or natural product. Gaining mechanistic knowledge towards such interactions has been accepted as an approach to avoid adverse reactions. The inductions and inhibition of CYP enzymes by natural products in the presence of a prescribed drug has led to adverse effects. Herbal medicines such as St. John's wort (Hypericum perforatum), garlic (Allium sativa), piperine (from Piper sp.), ginseng (Ginseng sp.), gingko (Gingko biloba), soya beans (Glycine max), alfalfa (Medicago sativa) and grape fruit juice show clinical interactions when co-administered with medicines. This review documents the involvement of CYP enzymes in the metabolism of known available drugs and herbal products. We also document the interactions between herbal constituents \& CYP enzymes showing potential drug-herb interactions. Data on CYP450 enzymes in activation (i.e. induction or inhibition) with natural constituents is also reviewed.
\end{abstract}

Keywords: Cytochrome P450; CYP; Herb-drug interactions; inhibition; induction; natural products; natural ingredients; phytomolecules

\section{Background:}

The name Cytochrome P450 derives from the fact that these proteins have a haem group, and an unusual absorption spectrum range. The reason for cytochrome $\mathrm{P} 450$ to absorb in this range is due to the unusual ligand haem iron. Four ligands are provided by nitrogen on the haem ring. The CYP enzymes are a superfamily of haem containing enzymes. In humans, CYP enzymes are important in the production of compounds such as cholesterol, corticosteroids and fatty acids. The most important feature of the CYP enzymes is its unique ability to activate molecular oxygen and to subsequently insert a single oxygen atom stereo-specifically into inert chemical bonds. CYP enzymes catalyses the insertion of oxygen into activated carbon - hydrogen bonds to yield alcohol (e.g. $\mathrm{RH}+\mathrm{O}_{2}+2 \mathrm{H}^{+}+2 \mathrm{e}^{-} \rightarrow \mathrm{ROH}+\mathrm{H}_{2} \mathrm{O}$ ). However, they can also carry out plethora of other reactions including epoxidation, dealkylation and heteroatom oxidation [1]. The majority of serious cases of drug interactions are as a result of the interference of the metabolic clearance of one drug by yet another co-administered drug, food or natural product. Gaining mechanistic knowledge towards such interactions has been accepted as an approach, for avoiding adverse reactions. The CYP P450 enzymes, which interact

ISSN 0973-2063 (online) 0973-8894 (print)

Bioinformation 3(5): 198-204 (2008) with a plethora of drugs available in the market, have been associated with a majority of the metabolism-related drugdrug interactions known to date [2, 3]. It is not surprising that much of the CYP in human is found in the liver, the main organ for drug and toxin removal. However, a significant amount is also found in the small intestine. There are over a thousand different types of CYP known till date. Nevertheless, the number of CYP types in human is relatively less.

The P450 proteins are categorized into families and subfamilies using sequence similarity. Sequences that are greater than $40 \%$ identity are considered within a family. Sequences that are greater than $55 \%$ identity are considered within a super-family. Humans have 57 CYP genes and more than 59 pseudo-genes divided among 18 families of CYP P450 genes and 43 subfamilies. The summary of the genes and proteins encoded is given in Table 1 (supplementary material). Several of them have been identified as particularly important in oxidative metabolism. They are CYP3A4 (by far the most important), CYP2D6, CYP2C9, and CYP2C19. Other notable CYPs are CYP2E1, CYP2A6 and CYP1A2. 


\section{www.bioinformation.net}

\section{Current Trends}

Enzyme induction occurs for CYP with appropriate substrates. The activity of CYP oxidases do vary across population due to polymorphism. Such differences in activity have clinical consequences, especially when multiple drugs are co-administered.

\section{Biological description of cytochrome $\mathbf{P 4 5 0}$}

The CYP enzymes involved in drug metabolism in humans are expressed predominantly in the liver. However, it is also present in large and small intestines, lungs and brain. They are insoluble proteins bound to the endoplasmic reticulum, with complex mechanistic and structural features. However, the first crystal structures of mammalian CYP enzymes have recently been determined, namely CYP2C5, CYP2B4, CYP2C9 and CYP3A4 $[4,5]$ and thus, much progress can be expected in this area in near future. It is believed that 15-20 different CYP enzyme isoforms contribute to drug metabolism in the human liver. However, the CYP enzymes 1A2, 2C9, 2C19, 2D6, 2E1 and 3A4 are considered most important among them [1, 2, 6]. These have different yet complementary substrate specificities with ability to metabolize a vast array of xenobiotics. CYP3A4 acts on most lipophilic substrates and is known to metabolize $>50 \%$ of the drugs in the liver [7], whilst CYP2D6 exhibits a preference for positively charged molecules, usually with a basic nitrogen. CYP2C9 metabolizes weakly anionic molecules, CYP1A2 uses poly-aromatic hydrocarbons and CYP2E1 uses small and soluble organics. Therefore, the CYP system can metabolize almost any organic xenobiotic $[7,8]$. Most drugs are cleared by CYP proteins. Drugs can increase or decrease the activity of one or more CYP enzymes, which alters the rate at which the drug is degraded and cleared from the body. This can work both ways. When a drug increases the activity of a CYP protein, CYP can render the drug ineffective, because it is cleared too quickly from the body. Alternatively, when a drug inhibits a CYP protein, CYP may not prevent the drug from accumulating to toxic levels, even to the extent of causing an overdose. CYP1, CYP2, CYP3 and CYP4 are the most important for drug biotransformation among CYP proteins and CYP3A4 is the most prevalent CYP in the body and is known metabolise several drugs [9, 10, 11].

\section{Metabolism based interactions}

The most common form of drug interactions entail a foreign chemical acting either as an inhibitor or an inducer of the CYP enzyme isoform responsible for metabolizing an administered medicinal drug, subsequently leading to an unusually slow or fast clearance of the drug. More rarely, enzyme stimulation can occur where direct addition of one compound enhances the rate of reaction for substrate [3]. Inhibition of drug metabolism will result in an elevation of its concentration in tissues. This leads to various adverse reactions, particularly for drugs with a low therapeutic index. Constant research in this field has been successfully kept updated by developing web based databases for reported and likely drug candidate interactions. The induction of a CYP enzyme isoform responsible for the metabolism of a drug can

ISSN 0973-2063 (online) 0973-8894 (print)

Bioinformation 3(5): 198-204 (2008) reduce its expected therapeutic capacity due to depletion of its plasma concentration. A higher dose of the parent drug is therefore required for effective therapy, with further dosage tailoring as and when the inducer effects are withdrawn. This is true in many instances. It should be note that CYP enzyme induction rarely leads to toxicity, except in cases where the metabolite is particularly harmful. For example, CYP1A1 and $1 \mathrm{~A} 2$ have been implicated in increased carcinogenic activation of chemicals. Thus they are considered as a potential risk factor in certain cancers and hence drugs that induce these reactions are preferentially avoided by the pharmaceutical industry [10, 12]. Several popular herbs have been reported to participate in interactions with medicinal drugs leading to clinically relevant drug adversities. A few examples that involve CYP enzymes and are highlighted in this review along with predicted as well as experimental interactions are summarized in Table 2 (supplementary material). A few examples of herbal constituents and drugs that interact with human CYP enzymes are highlighted in Table 3 (see supplementary material).

\section{Hypeforin from St. John's Wort herb (Hypericum perforatum)}

A popular herb largely used in the treatment of depression is St. John's Wort (SJW). It has been implicated with a number of clinically significant interactions with medicinal drugs, one of the more potentially fatal being with cyclosporine. Cyclosporine is an immunosuppressant with a narrow therapeutic index administered to transplant patients. In reported cases, consumption of various levels of SJW (from $300 \mathrm{mg}$ /day for 4 weeks to 2 or $3 \times 300 \mathrm{mg} /$ day for 6 months) lead to a decrease in cyclosporine levels below the desirable effective therapeutic range of $200-350 \mu \mathrm{g} / \mathrm{L}$ causing cellular rejection of the tissue [13]. The induction of CYP3A4 through the activation of pregnane X-receptor by both the crude extract and hyperforin (one of the active ingredients) has been demonstrated in primary human hepatocyte cultures. In addition, the induction of intestinal multidrug resistant transporter protein MDR1/P-glycoprotein has been demonstrated in clinical and preclinical (rat in vivo) investigations [14, 15]. Results of these studies explain the combined increase in absorption and metabolism of drugs such as cyclosporine in the presence of SJW, thus resulting in a severe decrease in the serum availability of the drug leading to declined therapy. They also provide a mechanism-based explanation for other SJW-mediated adversities in the presence of prescription medicines whose metabolism is catalyzed by CYP3A4. Such instances include the loss of anticoagulant activity of warfarin and the intermenstrual bleeding in several females on the contraceptive, ethinylestradiol $[16,17]$. A recent clinical study examining the metabolism of omeprazole has established that in addition to the induction of CYP3A4, SJW enormously decreases the plasma concentration of the drug through the induction of CYP2C19, which is responsible for the hydroxylation of the drug [18]. 


\section{Allicin from Garlic (Allium sativum)}

Garlic is used for the reduction of hypertension and hyperlipidaemia. It has been implicated in the decrease of the plasma concentration of protease inhibitor saquinavir [19, 20]. The induction of gut CYP3A4 by garlic was thought to be a plausible explanation for the reduction in bioavailability of the drug known to be primarily metabolized by CYP3A4 [21]. The active ingredient allicin has also shown potent inhibitory activity on CYP2C9 and 2C19. The potential drug adversities predicted for each of these active ingredients as a result of their interactions with CYP enzymes has to be examined in a clinical setting to know the extent to which garlic can interact with co-medications [20, 22].

\section{Piperine from Piper (Piper nigrum)}

In clinical trials, piperine has shown to increase the bioavailability of phenytoin, propranolol and theophylline [23]. Although in vivo study on rat has demonstrated that piperine treatment suppressed CYP2E1 expression and enhanced $2 \mathrm{~B}$ and $1 \mathrm{~A}$ expression $[12,24]$. It should be noted that the clinical observations are due for CYP isoforms for further research.

\section{Ginsenoside from Ginseng (Panax ginseng)}

Ginseng (Panax ginseng) has been shown to induce mania when used concomitantly with phenelzine [25]. Bipolar disorder (mania) also known as manic depression (or bipolar depression) and is a common mood disorder that affects $\begin{array}{llll}\text { about } & 5.7 & \text { million }\end{array}$ (www.medicinenet.com/bipolar_disorder/article.htm). In vitro studies using both crude ginseng extract and total saponins at high concentrations $(>2000 \mu \mathrm{g} / \mathrm{mL})$ showed the inhibition of CYP2E1 activity in mouse and human microsomes [26]. Ginsenoside caused weak inhibitory activity against CYP3A4, CYP2D6, CYP2C19 and CYP2C9 while ginsenoide increased the activity of CYP2C9 and CYP3A4 [26, 27]. The effect of this herb and its ingredients on CYP enzymes is yet to be substantiated in an in vivo context.

\section{Ginkgolic acid from Gingko (Gingko biloba)}

In vitro and in vivo analysis carried out on hepatic and intestinal CYP enzymes of rat, have demonstrated that the leaf extract inhibits the metabolism of diltiazem, which is a typical substrate for CYP3A [28] and also induces CYP2B enzymes [29]. In addition, ginkgolic acids were shown to be potent inhibitors of CYP1A2, CYP2C9 and CYP2C19 under CYP enzymes case study [30]. Although flavanol aglycones showed significant inhibitory activity against CYP1A2, 2C9 and $3 \mathrm{~A}$, recent findings showed that the most abundant components of gingko preparations in clinical use (terpene trilactones and flavanol glycosides) do not significantly inhibit major CYP enzymes in microsomes of human's liver [16, 22, 29]. The variations of constituents of gingko (ginkgolides, biobalides, and flavone glycosides) and their bioavailabilities could explain the disparity in findings, in addition to species variability in drug metabolism.

\section{Pharmacovigilance}

The under-reporting of adverse drug reactions in developing countries including India, Sri Lanka and the Philippines [31], is possibly the main reason why only $3 \%$ of the adverse drug reactions reported in the WHO database have been added from the developing countries where approximately $80 \%$ of the world's population lives. In these countries, a strong practice of traditional medicine exists and adverse drug reactions go unrecognized as part of the healing process. There is generally a misconception that natural therapies are safe. The reluctance of physicians trained in Western medicine to give recognition to these traditional practices also leads to a lack of acknowledgement of possible drugherb interactions [32]. The world consumption of natural products for medicinal purposes is immense. According to WHO estimates, $30-50 \%$ of total medicinal consumption in China can be accounted by herbal preparations, $70 \%$ of Canadians and $>50 \%$ of Europeans, North Americans and persons living in other industrialized regions have used complementary medicine at least once, in addition to the high incidence of practice in Africa, Latin America and Asia [8, $33,34]$

\section{Future prospects:}

The role of metabolism in drug-herb components interactions and in turn the role of CYP enzymes in such interactions cannot be overstated. Studies that could establish the various phenotypes and genotypes of CYP alleles for populations in various ethnic groups, the impact of environmental, dietary and social habits on CYP activity, the metabolism of natural products by CYP enzymes and the impact of these natural products on the CYP enzyme activities would allow initial predictions. Hence, prevention of likely adverse drug reactions involving these crucial enzymes is possible. Gaining a mechanism based understanding lies at the root of avoiding these enzyme-related drug adversities. Cytochrome P450 is an ideal target for these studies. The ability to make such predictions would be of enormous benefit to pharmacogenomics studies as P450 plays a vital role in the metabolism of drugs. The Cytochrome is of special interest in pharmacology as it is responsible for the metabolism of many pharmacologically active molecules. The use of in silico protein-drug interactions studies and computer aided drug designing approach and quantum mechanical calculations will allowing to know the mechanism of interaction of P450 with herbal constituents. This in turn will allow theories regarding unknown features of human P450 to be tested and predictions to be made for the result of an interaction of herbal constituents within a given P450. The computational approaches could be used to analyze the interactions, regarding the processes on such binding which helps to predict new conformations of active site. The introduction of some of the determined contact residues of the active site into the model will allow the orientation of herbal constituents and lead molecules. 


\section{Bioinformation}

www.bioinformation.net
Acknowledgment:

We acknowledge the Council of Scientific and Industrial Research (CSIR), New Delhi and Department of Biotechnology (DBT), New Delhi for financial supports to the Central Institute of Medicinal and Aromatic Plants (CIMAP), Lucknow (UP), INDIA.

\section{References:}

[01] B. Meunier et al., Chem. Rev., 104: 3947 (2004)

[02] D. Werck-Reichhart and R. Feyereisen, Genome Biology review, 1: 3003.1 (2000)

[03] J. M. Sorensen, J Altern Complement Med., 8: 293 (2002)

[04] J. D. Marechal et al., British Journal of Pharmacology, 153: S82 (2008)

[05] S. Modi et al., Biochemistry, 35: 4540 (1996)

[06] K. N. Degtyarenko, Protein Engineering, 8: 737 (1995)

[07] F. Guengerich, The AAPS Journal, 8: 12 (2006)

[08] F. Guengerich, Adv Pharmacol., 7: 35 (1997)

[09] J. M. Meyer and K. A. Rodvold, Infect Med., 13: 463 (1996)

[10] T. Munasinghe, Ceylon Med J. , 47: 19 (2002)

[11] P. Glue and R. P. Clement, Cellular and Molecular Neurobiology, 19: 3 (1999)

[12] J. A. Johnson et al., J Pharmacol Exp Ther., 294: $1099(2000)$

[13] G. W. Barone et al., Ann Pharmacotherapy, 34: 1013 (2000)

[14] D. Durr et al., Clin Pharmacol Ther., 68: 598 (2000)
[15] U. A. Meyer and U. M. Zanger, Annu Rev Pharmacol Toxicol., 37: 269 (1997)

[16] A. D. Rodrigues and S. Wong, London: Scientific and Regulatory Perspectives, 65: 101 (1997)

[17] Q. Yue et al., Lancet, 355: 576 (2000)

[18] L. Wang et al., Clin Pharmacol Ther.,75: 191 (2004)

[19] D. Guyonnet et al., Mutat Res., 466: 17 (2000)

[20] S. Piscitelli et al., Clin Infect Dis., 34: 234 (2001)

[21] B. C. Foster et al., J Pharm Pharm Sci., 4: 176 (2001)

[22] L. Zou et al., Life Sci., 71: 1579 (2002)

[23] G. Bano et al., Eur J Clin Pharmacol., 41: 615 (1991)

[24] M. Kang et al., Xenobiotica., 24: 1195 (1994)

[25] B. Jones and A. Runikis, J Clin Psychopharmacol., 7: 201 (1987)

[26] G. Henderson et al., Life Science, 65: 209 (1999)

[27] B. J. Gurley et al., Clin Pharmacol Ther., 72: 276 (2002)

[28] N. Ohnishi et al., Biol Pharm Bull., 26: 1315 (2003)

[29] L. L. Moltke et al., J Pharm Pharmacol., 56: 1039 (2004)

[30] A. D. Rodrigues, Biochem Pharmacol., 48: 2147 (1994)

[31] T. Omura, Biochemical and Biophysical Research Communications, 266: 690 (1999)

[32] R. J. Riley, Curr Opin Drug Discov Devel., 4: 45 (2002)

[33] B. Foster et al., J Pharm Pharm Sci., 52: 185 (2002)

[34] K. Ishihara et al., J Pharm Pharmacol., 52: 1023 (2000)

Edited by P. Kangueane

Citation: Saxena et al., Bioinformation 3(5): 198-204 (2008)

License statement: This is an open-access article, which permits unrestricted use, distribution, and reproduction in any medium, for non-commercial purposes, provided the original author and source are credited. 
www.bioinformation.net

Current Trends

\section{Supplementary material}

\begin{tabular}{|c|c|c|c|}
\hline $\begin{array}{c}\text { CYP } \\
\text { family }\end{array}$ & Function & Category & $\begin{array}{c}\text { CYP } \\
\text { Isoform }\end{array}$ \\
\hline CYP1 & Drug and steroid (especially estrogen) metabolism & $\begin{array}{l}3 \text { subfamilies, } \\
3 \text { genes, } \\
1 \text { pseudogene }\end{array}$ & $\begin{array}{l}\text { CYP1A1 } \\
\text { CYP1A2 } \\
\text { CYP1B1 }\end{array}$ \\
\hline CYP2 & Drug and steroid metabolism & $\begin{array}{l}13 \text { subfamilies, } \\
16 \text { genes, } \\
16 \text { pseudogenes }\end{array}$ & $\begin{array}{l}\text { CYP2A6 CYP2A7 CYP2A13 } \\
\text { CYP2B6 } \\
\text { CYP2C8 } \\
\text { CYP2C9 CYP2C18 CYP2C19 } \\
\text { CYP2D6 } \\
\text { CYP2E1 } \\
\text { CYP2F1 } \\
\text { CYP2J2 } \\
\text { CYP2R1 } \\
\text { CYP2S1 } \\
\text { CYP2U1 } \\
\text { CYP2W1 }\end{array}$ \\
\hline CYP3 & Drug and steroid (including testosterone) metabolism & $\begin{array}{l}1 \text { subfamily, } \\
4 \text { genes, } \\
2 \text { pseudogenes }\end{array}$ & $\begin{array}{l}\text { CYP3A4 CYP3A5 CYP3A7 } \\
\text { CYP3A43 }\end{array}$ \\
\hline CYP4 & Arachidonic acid or fatty acid metabolism & $\begin{array}{l}6 \text { subfamilies, } \\
11 \text { genes, } \\
10 \text { pseudogenes }\end{array}$ & $\begin{array}{l}\text { CYP4A11 CYP4A22 CYP4B1 } \\
\text { CYP4F2 } \\
\text { CYP4F3 } \\
\text { CYP4F8 CYP4F11 CYP4F12 } \\
\text { CYP4F22 CYP4V2 CYP4X1 } \\
\text { CYP4Z1 }\end{array}$ \\
\hline CYP5 & Thromboxane A2 synthase & $\begin{array}{l}1 \text { subfamily, } \\
1 \text { gene }\end{array}$ & CYP5A1 \\
\hline CYP7 & Bile acid biosynthesis 7-alpha hydroxylase of steroid nucleus & $\begin{array}{l}2 \text { subfamilies, } \\
2 \text { genes }\end{array}$ & $\begin{array}{l}\text { CYP7A1 } \\
\text { CYP7B1 }\end{array}$ \\
\hline CYP8 & Varied & $\begin{array}{l}2 \text { subfamilies, } \\
2 \text { genes }\end{array}$ & $\begin{array}{l}\text { CYP8A1 (prostacyclin synthase), } \\
\text { CYP8B1 (bile acid biosynthesis) }\end{array}$ \\
\hline CYP11 & Steroid biosynthesis & $\begin{array}{l}2 \text { subfamilies, } \\
3 \text { genes }\end{array}$ & CYP11A1 CYP11B1 CYP11B2 \\
\hline CYP17 & Steroid biosynthesis, 17 -alpha hydroxylase & $\begin{array}{l}1 \text { subfamily, } \\
1 \text { gene }\end{array}$ & CYP17A1 \\
\hline CYP19 & Steroid biosynthesis: aromatase synthesizes estrogen & $\begin{array}{l}1 \text { subfamily, } \\
1 \text { gene }\end{array}$ & CYP19A1 \\
\hline CYP20 & Unknown function & $\begin{array}{l}1 \text { subfamily, } \\
1 \text { gene }\end{array}$ & CYP20A1 \\
\hline CYP21 & Steroid biosynthesis & $\begin{array}{l}2 \text { subfamilies, } \\
2 \text { genes, } \\
1 \text { pseudogene }\end{array}$ & CYP21A2 \\
\hline CYP24 & Vitamin d degradation & $\begin{array}{l}1 \text { subfamily, } \\
1 \text { gene }\end{array}$ & CYP24A1 \\
\hline CYP26 & Retinoic acid hydroxylase & $\begin{array}{l}3 \text { Subfamilies, } \\
3 \text { genes }\end{array}$ & CYP26A1 CYP26B1 CYP26C1 \\
\hline
\end{tabular}




\section{www.bioinformation.net}

Current Trends

\begin{tabular}{|c|c|c|c|}
\hline CYP27 & Varied & $\begin{array}{l}3 \text { subfamilies, } \\
3 \text { genes }\end{array}$ & $\begin{array}{l}\text { CYP27A1 (bile acid biosynthesis), } \\
\text { CYP27B1 (vitamin D3 1-alpha } \\
\text { hydroxylase, activates vitamin D3) } \\
\text { CYP27C1 (unknown function) }\end{array}$ \\
\hline CYP39 & 7-alpha hydroxylation of 24-hydroxycholesterol & $\begin{array}{l}1 \text { subfamily, } \\
1 \text { gene }\end{array}$ & CYP39A1 \\
\hline CYP46 & Cholesterol 24-hydroxylase & $\begin{array}{l}1 \text { subfamily, } \\
1 \text { gene }\end{array}$ & CYP46A1 \\
\hline CYP51 & Cholesterol biosynthesis & $\begin{array}{l}1 \text { subfamily, } \\
1 \text { gene, } \\
3 \text { pseudogenes }\end{array}$ & $\begin{array}{l}\text { CYP51A1 (lanosterol 14-alpha } \\
\text { demethylase) }\end{array}$ \\
\hline
\end{tabular}

Table 1: Classification of the CYP family on the basis of CYP isoform and function is given.

\begin{tabular}{|c|c|c|c|c|}
\hline S. No. & $\begin{array}{c}\text { Name of medicinal } \\
\text { plant }\end{array}$ & $\begin{array}{l}\text { Herbal component } \\
\text { and Chemical } \\
\text { formula }\end{array}$ & IUPAC name & $\begin{array}{l}\text { PubChem } \\
\text { CID* }\end{array}$ \\
\hline 1. & $\begin{array}{l}\text { St.John's wort } \\
\text { (Hypericum } \\
\text { perforatum) }\end{array}$ & $\begin{array}{l}\text { Hyperforin } \\
\mathrm{C}_{35} \mathrm{H}_{52} \mathrm{O}_{4}\end{array}$ & $\begin{array}{l}\text { 4-Hydroxy-5-isobutyryl-6-methyl-1,3,7-tris-(3- } \\
\text { methyl-but-2-enyl)-6-(4-methyl-pent-3-enyl)- } \\
\text { bicyclo[3.3.1]non-3-ene-2,9-dione }\end{array}$ & 5288591 \\
\hline 2. & $\begin{array}{l}\text { Garlic } \\
\text { (Allium sativum) }\end{array}$ & $\begin{array}{l}\text { Allicin } \\
\mathrm{C}_{6} \mathrm{H}_{10} \mathrm{OS}_{2}\end{array}$ & 3-prop-2-enylsulfinylsulfanylprop-1-ene & 65036 \\
\hline 3. & $\begin{array}{l}\text { Piperine } \\
\text { (Piper nigrum) }\end{array}$ & $\begin{array}{l}\text { Piperine } \\
\mathrm{C}_{17} \mathrm{H}_{19} \mathrm{NO}_{3}\end{array}$ & $\begin{array}{l}\text { (2E,4E)-5-(1,3-benzodioxol-5-yl)-1-piperidin-1- } \\
\text { ylpenta-2,4-dien-1-one }\end{array}$ & 638024 \\
\hline 4. & $\begin{array}{l}\text { Ginseng } \\
\text { (Panax ginseng) }\end{array}$ & $\begin{array}{l}\text { Ginsenoside } \\
\mathrm{C}_{30} \mathrm{H}_{52} \mathrm{O}_{2}\end{array}$ & $\begin{array}{l}\text { (3S,5R,8R,9R,10R,14R,17S)-17-(2-hydroxy-6- } \\
\text { methylhept-5-en-2-yl)-4,4,8,10,14-pentamethyl- } \\
\text { 2,3,5,6,7,9,11,12,13,15,16,17-dodecahydro-1H- } \\
\text { cyclopenta[a]phenanthren-3-ol }\end{array}$ & 3086007 \\
\hline 5. & $\begin{array}{l}\text { Gingko } \\
\text { (Ginkgo biloba) }\end{array}$ & $\begin{array}{l}\text { Ginkgolic acid } \\
\mathrm{C}_{22} \mathrm{H}_{34} \mathrm{O}_{3}\end{array}$ & 2-hydroxy-6-[(Z)-pentadec-8-enyl]benzoic acid & 5281858 \\
\hline
\end{tabular}

Table 2: Medicinal plants with their herbal components, IUPAC name, Chemical structure and PubChem CID number. (Note: *

= PubChem compound identity descriptor number (http://pubchem.ncbi.nlm.nih.gov/)).

\begin{tabular}{|c|c|c|c|c|c|c|c|}
\hline S. No. & $\begin{array}{l}\text { Medicinal } \\
\text { plant }\end{array}$ & $\begin{array}{c}\text { Herbal } \\
\text { constituent } \\
\text { and } \\
\text { chemical } \\
\text { formula }\end{array}$ & Drug & $\begin{array}{l}\text { Experimental } \\
\text { model }\end{array}$ & $\begin{array}{c}\text { CYP } \\
\text { enzyme } \\
\text { involved } \\
\text { (isoform) }\end{array}$ & $\begin{array}{l}\text { Symptom of } \\
\text { interaction }\end{array}$ & Mechanism \\
\hline 1. & $\begin{array}{l}\text { St. John's } \\
\text { wort } \\
\text { (Hypericum } \\
\text { perforatum) }\end{array}$ & $\begin{array}{l}\text { Hyperforin } \\
\mathrm{C}_{35} \mathrm{H}_{52} \mathrm{O}_{4}\end{array}$ & Ciclosporin & $\begin{array}{l}\text { Human } \\
\text { hepatocytes }\end{array}$ & $\begin{array}{l}\text { CYP3A4, } \\
2 \mathrm{E} 1,2 \mathrm{C} 19\end{array}$ & $\begin{array}{l}\text { Reduction in } \\
\text { serum }\end{array}$ & $\begin{array}{l}\text { Induction of p- } \\
\text { glycoprotein }\end{array}$ \\
\hline 2. & $\begin{array}{l}\text { St. John's } \\
\text { wort } \\
\text { (Hypericum } \\
\text { perforatum) }\end{array}$ & $\begin{array}{l}\text { Hyperforin } \\
\mathrm{C}_{35} \mathrm{H}_{52} \mathrm{O}_{4}\end{array}$ & Warfarn & $\begin{array}{l}\text { Human clinical } \\
\text { trail }\end{array}$ & CYP3A4 & $\begin{array}{l}\text { Loss of } \\
\text { anticoagulant } \\
\text { activity }\end{array}$ & $\begin{array}{l}\text { Inhibition of } \\
\text { CYP activity }\end{array}$ \\
\hline 3. & $\begin{array}{l}\text { St. John's } \\
\text { wort } \\
\text { (Hypericum } \\
\text { perforatum) }\end{array}$ & $\begin{array}{l}\text { Hyperforin } \\
\mathrm{C}_{35} \mathrm{H}_{52} \mathrm{O}_{4}\end{array}$ & Omeprazole & $\begin{array}{l}\text { Human clinical } \\
\text { trail }\end{array}$ & CYP2C19 & $\begin{array}{l}\text { Decreases Plasma } \\
\text { concentration }\end{array}$ & $\begin{array}{l}\text { Induction of } \\
\text { CYP2C19, } \\
3 \text { A4 }\end{array}$ \\
\hline 4. & $\begin{array}{l}\text { Garlic } \\
\text { (Allium } \\
\text { sativum) }\end{array}$ & $\begin{array}{l}\text { Allicin } \\
\mathrm{C}_{6} \mathrm{H}_{10} \mathrm{OS}_{2}\end{array}$ & Sequinavir & $\begin{array}{l}\text { Human clinical } \\
\text { trail }\end{array}$ & CYP3A4 & $\begin{array}{l}\text { Reduction of } \\
\text { hypertension }\end{array}$ & $\begin{array}{l}\text { Inhibition of } \\
\text { CYP2C9, } \\
\text { 2C19, 3A4 }\end{array}$ \\
\hline 5. & $\begin{array}{l}\text { Garlic } \\
\text { (Allium } \\
\text { sativum) }\end{array}$ & $\begin{array}{l}\text { Allicin } \\
\mathrm{C}_{6} \mathrm{H}_{10} \mathrm{OS}_{2}\end{array}$ & Sequinavir & $\begin{array}{l}\text { Human clinical } \\
\text { trail }\end{array}$ & $\begin{array}{l}\text { CYP2C9, } \\
2 \mathrm{C} 19\end{array}$ & $\begin{array}{l}\text { Reduction of } \\
\text { hypertension and } \\
\text { hyperlipidameia }\end{array}$ & $\begin{array}{l}\text { Inhibition of } \\
\text { CYP2C9, } \\
\text { 2C19 }\end{array}$ \\
\hline
\end{tabular}


Bioinformation

open access

\section{www.bioinformation.net}

Current Trends

\begin{tabular}{|c|c|c|c|c|c|c|c|}
\hline 6. & $\begin{array}{l}\text { Black } \\
\text { Pepper } \\
\text { (Piper } \\
\text { nigrum) }\end{array}$ & $\begin{array}{l}\text { Piperine } \\
\mathrm{C}_{17} \mathrm{H}_{19} \mathrm{NO}_{3}\end{array}$ & Antimicrobial & $\begin{array}{l}\text { In vivo studies in } \\
\text { rat }\end{array}$ & CYP2E1 & $\begin{array}{l}\text { suppressed } \\
\text { CYP2E1 } \\
\text { expression }\end{array}$ & $\begin{array}{l}\text { Induce activity } \\
\text { of } \\
\text { CYP 1A, 2B }\end{array}$ \\
\hline 7. & $\begin{array}{l}\text { Ginseng } \\
\text { (Panax } \\
\text { ginseng) }\end{array}$ & $\begin{array}{l}\text { Ginsenoside } \\
\mathrm{C}_{42} \mathrm{H}_{72} \mathrm{O}_{14} \\
\text { Ginsenoide }\end{array}$ & Phenelzine & $\begin{array}{l}\text { In vitro studies in } \\
\text { mouse and human } \\
\text { microsomes }\end{array}$ & CYP2E1 & $\begin{array}{l}\text { Induce CYP3A4, } \\
\text { 2D6, 2C19, 2C9 } \\
\text { activity }\end{array}$ & $\begin{array}{l}\text { Inhibition of } \\
\text { CYP2E1 } \\
\text { activity }\end{array}$ \\
\hline 8. & $\begin{array}{l}\text { Gingko } \\
\text { (Gingko } \\
\text { biloba) }\end{array}$ & $\begin{array}{l}\text { Ginkgolic } \\
\text { acid } \\
\mathrm{C}_{22} \mathrm{H}_{34} \mathrm{O}_{3}\end{array}$ & Diltiazem & $\begin{array}{l}\text { In vitro and in } \\
\text { vivo analysis on } \\
\text { rat hepatic and } \\
\text { intestinal CYP } \\
\text { enzymes }\end{array}$ & $\begin{array}{l}\text { CYP3A, } \\
2 \mathrm{~B}\end{array}$ & $\begin{array}{l}\text { Inhibit } \\
\text { metabolism of } \\
\text { Diltiazem (drug) }\end{array}$ & $\begin{array}{l}\text { Induces } \\
\text { CYP2B and } \\
\text { inhibit } \\
\text { CYP1A2, C9 } \\
\text { 2C19 }\end{array}$ \\
\hline
\end{tabular}

Table 3: Assessment of herbal components on drug interactions and effects on CYP activities 